\title{
EFFECTS OF IRRIGATION AND NITROGEN ON YIELD AND WATER PRODUCTIVITY IN COMMON BEAN (PHASEOLUS VULGARIS L.) AND COWPEA (VIGNA UNGUICULATA L.) IN NORTH OF IRAN
}

\author{
NOURALINEZHAD, A. ${ }^{1}-$ BABAZADEH, H. $^{1 *}-$ AMIRI, E. $^{2}-$ SEDGHI, H. ${ }^{1}$ \\ ${ }^{I}$ Department of Water Engineering, Science and Research Branch, Islamic Azad University \\ Tehran, Iran \\ (e-mails: alirezanouralinezhad@yahoo.com; h_sedghi@srbiau.ac.ir) \\ ${ }^{2}$ Department of Water Engineering, Lahijan Branch, Islamic Azad University, Lahijan, Iran \\ (e-mail:eamiri57@yahoo.com) \\ *Corresponding author \\ e-mail:h_babazadeh@srbiau.ac.ir \\ (Received $19^{\text {th }}$ Dec 2017; accepted $10^{\text {th }}$ May 2018)
}

\begin{abstract}
Water is known as a critical and rare source that humans and ecological systems depend on. With growing population and developing technologies in many countries, availability to this critical source has been decreased. This research was conducted in a split plot experiment in a randomized complete block design with 3 replications in Iran (the north of Iran, Astaneh-ye-Ashrafiyeh). The main treatments were irrigation with 40,60, 80 and $100 \%$ water requirement using water balance and direct method and the second treatments were 0 and 30,60 and $90 \mathrm{~kg} \mathrm{~N} \mathrm{ha}^{-1}$, and two bean cultivars were tested (local Dehsari and Cowpea). Seed yield in 2016 and 2017, in the case of irrigation with100\% water requirement and $60 \mathrm{~kg} \mathrm{~N}$ ha $^{-1}$ was higher in common bean cultivar than in Cowpea and yields were 3486 and $3646 \mathrm{~kg} \mathrm{ha}^{-1}$, respectively. The highest water use productivity in seed yield in 2016 and 2017 was in common bean cultivar, and in the case of irrigation with $100 \%$ water requirement and $60 \mathrm{~kg} \mathrm{~N} \mathrm{ha}^{-1}$ fertilizer added, levels were 0.70 and $0.69 \mathrm{~kg} \mathrm{~m}^{-3}$, respectively.
\end{abstract}

Keywords: fertilizer, plant production, water requirements, water productivity, yield component

\section{Introduction}

Agricultural sections, known as the largest consumers of water, create many challenges in producing foods with less consumed water. In recent years, competitions for getting more water sources among industry, agriculture and urban sections have increased, therefore, the optimum water consumption is a priority for the agricultural industry. Legumes, after cereals, are the second main food. The protein content in legumes is two or three times higher than in cereals and Iran is the second largest producer of legumes. Cowpeas are summer crops which grow in African tropical and subtropical regions (Jean-Martial et al., 2013). Cowpea is cultivated in north of Mexico and south-west of America and since they are resistant to high temperature, they have known as an important crop for hot regions (Jean-Martial et al., 2013; Singh, 2004; Hall et al., 2003; Clavel et al., 2005; Shardendu et al., 2011). Common bean contains 20$25 \%$ protein and 50-56\% carbohydrate, and comparing to cereal and starch crops, it contains 2-3 and 10-20 times more protein, respectively (Carmona-Garcia et al., 2007). Water is a critical parameter which influences these crops significantly (Kotchoni and Bartels, 2003). Drought stress is known as one of the main reasons for crop loss which leads to 50\% decrease in efficiency (Singh, 2007). Water shortage stress resulted in the 
decrease of growth of the crops and decreased the efficiency (Korir et al., 2006). About $60 \%$ of beans experienced alternative droughts and/or droughts for the end of the season (Beebe et al., 2008). The vegetative growth period of crops is an important and long period in crop cultivation (Baker and Rosenqvist, 2004). The decrease of this period in beans resulted in significant changes in growth and biological functions (Baker and Rosenqvist, 2004). Nitrogen is a critical element and is involved in producing the chlorophyll molecule that plays an important role in photosynthesis (Fageria and Santos, 2008). One-third of the world's most cultivated lands faces a shortage of water for agriculture, which is characterized by climate change and the increasing population will make this problem more serious in the future. Understanding the detrimental effects of drought on plant processes and mechanisms of drought tolerance in crop species, particularly those adapted to dry conditions will help to improve their agronomic performance by incorporating the superior traits into new species or cultivars (Clavel et al., 2005; Shardendu et al., 2011). Therefore, identification of plants resistant to dryness or dehydrated condition with proper performance and their resistance mechanisms is one of the most important solutions to combat drought stress. Due to limited water resources and low rainfall in the Country, the prospect is uncertain for agricultural production. According to forecasts, with the warming of the Earth's crust in the Future, the water requirement of plants will increase and the use of water resources will be very limited. Increasing competition for obtaining water and supplying water needs for growth of products should be done with regular irrigation to prevent irrigation from drought and flooding, and provide a basis for optimizing water use (Aujla et al., 2005).

Water productivity is defined as the ratio of dry matter production to water use (Anyia and Herzog, 2004). water productivity might not provide much information about the competitive or yield advantage of one particular species over another because improved water productivity may actually restrict growth. However, it is one trait that has been studied a great deal because it can give an idea of the variation amongst genotypes in ability where water is limited. Nitrogen plays a critical role in synthesis of proteins and nucleic acids and the shortage of nitrogen is easily seen in old leaves (Fageria and Santos, 2008). This research aims to evaluate the effect of nitrogen and water requirement on bean crops in the region of the study.

\section{Materials and methods}

This study was conducted in north of Iran (Astaneh-ye-Ashrafiyeh) located in latitude 37 and 29 min and longitude 49 and $9553 \mathrm{~min}, 3 \mathrm{~m}$ below sea level on average in 2016 and 2017. In 2016 and 2017 rainfall was 65.7 and $76 \mathrm{~mm}$, respectively. The meteorology and soil physicochemical traits are shown in Table 1 and 2. This research was implemented in split plot and random complete block in Astaneh-ye-Ashrafiyeh and all experiments were repeated 3 times. The main variables were irrigation with 40 , 60,80 and $100 \%$ water requirement, $0,30,60$ and $90 \mathrm{~kg}$ nitrogen added per hectare and two bean varieties were tested (local Dehsari and Cowpea). In a plot, two rows were omitted and 12 crops were chosen randomly to evaluate the seed yield. The beans were removed and dried in oven with $70{ }^{\circ} \mathrm{C}$ for $48 \mathrm{~h}$. After drying, the samples were weighed with precision of 0.01 and converted to $\mathrm{kg} \mathrm{ha}^{-1}$. Cowpea was harvested in several turns and the average of 6 turns was evaluated. The drainage of soil moisture was considered as irrigation variable and the water requirement was considered to be $100 \%$ of 


$$
-3115-
$$

irrigation. Other variables were calculated based on irrigation value. In order to achieve $100 \%$ irrigation, the soil moisture near crops root was calculated using Equation 1.

$$
\mathrm{d}_{\mathrm{n}}=\left(\theta_{\mathrm{Fc}}-\theta_{\mathrm{i}}\right) \rho_{\mathrm{b}} \mathrm{D}_{\mathrm{r}}
$$

The soil moisture to height of root showed the farm capacity. The duration of irrigation was calculated based on receiving moisture by soil. The $\theta_{\mathrm{Fc}}$ is moisture percent of cultivation $(\% \mathrm{w}), \Theta_{\mathrm{i}}$ is soil moisture $(\% \mathrm{w}), \rho_{\mathrm{b}}$ is density $\left(\mathrm{gr} \mathrm{cm}^{-3}\right)$ and $\mathrm{D}_{\mathrm{r}}$ is effective root height $(\mathrm{cm})$. The efficiency of water was determined by dividing seed yield on consuming water (Passioura, 2006). The irrigation and consumed water in each sample during growing phase is shown in Table 3.

Water productivity (WP; Eq. 2) is the seed yield $(\mathrm{kg})$ per water use $\left(\mathrm{m}^{3}\right)$ :

$$
\text { WP }\left(\mathrm{kg} \mathrm{m}^{-3}\right)=\frac{\text { seed yield }(\mathrm{kg})}{\text { water use }\left(\mathrm{m}^{3}\right)}
$$

Variance analysis and average comparison were conducted by MSTATC software (Duncan test 5\%) and all figures were drawn in Excel software.

Table 1. Information on meteorological data

\begin{tabular}{c|c|c|c|c|c|c|c|c}
\hline \multirow{2}{*}{ During growth } & \multicolumn{2}{|c|}{$\begin{array}{c}\text { Maximum } \\
\text { temperature }\left({ }^{\circ} \mathbf{C}\right)\end{array}$} & \multicolumn{2}{c|}{$\begin{array}{c}\text { Minimum } \\
\text { temperature }\left({ }^{\circ} \mathbf{C}\right)\end{array}$} & \multicolumn{2}{c|}{$\begin{array}{c}\text { Average } \\
\text { humidity (\%) }\end{array}$} & \multicolumn{2}{|c}{ Rain (mm) } \\
\cline { 2 - 9 } & $\mathbf{2 0 1 6}$ & $\mathbf{2 0 1 7}$ & $\mathbf{2 0 1 6}$ & $\mathbf{2 0 1 7}$ & $\mathbf{2 0 1 6}$ & $\mathbf{2 0 1 7}$ & $\mathbf{2 0 1 6}$ & $\mathbf{2 0 1 7}$ \\
\hline June & 27.3 & 28.4 & 17.3 & 18.4 & 70.1 & 59.8 & 11.3 & 12.5 \\
July & 41.9 & 31.9 & 20 & 19 & 52.3 & 50 & 30.7 & 33.2 \\
August & 29.5 & 28.9 & 18.8 & 20.2 & 67.9 & 62.3 & 0 & 6.3 \\
September & 28.4 & 27.3 & 18.5 & 19.2 & 66.7 & 64.1 & 23.7 & 24 \\
\hline
\end{tabular}

Table 2. Characteristics of soil in the study area

\begin{tabular}{c|c|c|c|c|c|c}
\hline \multirow{2}{*}{ Soil depths (cm) } & \multicolumn{4}{|c|}{ Particle size distribution (\%) } & \multirow{2}{*}{ EC (\%) } & \multirow{2}{*}{ Total nitrogen (\%) } \\
\cline { 2 - 6 } & Sand & Silt & Clay & Organic carbon & & 27.1 \\
\hline $0-20$ & 47 & 32 & 21 & 0.65 & 0.646 & 28.5 \\
\hline $20-40$ & 46 & 34 & 20 & 0.71 & 0.653 & 2 \\
\hline
\end{tabular}

Table 3. The amount of water use in each treatment in 2016 and 2017

\begin{tabular}{c|c|c|c|c}
\hline Year & $\mathbf{2 0 1 6}$ & $\mathbf{2 0 1 7}$ & $\mathbf{2 0 1 6}$ & $\mathbf{2 0 1 7}$ \\
\hline Water requirements & \multicolumn{2}{|c|}{ Amount of irrigation $\mathbf{( m m )}$} & \multicolumn{2}{|c}{ Amount of water use (mm) } \\
\hline $40 \%$ & 162 & 175 & 366.7 & 251 \\
$60 \%$ & 243 & 262.5 & 308.7 & 338.5 \\
$80 \%$ & 324 & 350 & 389.7 & 426 \\
$100 \%$ & 403.1 & 436.2 & 468.8 & 512.2 \\
\hline
\end{tabular}




$$
\text { - } 3116-
$$

\section{Results}

\section{Seed yield}

The relations between bean crops and nitrogen fertilizer in seed yield in 2016 and 2017 were significant in level 5\% and other changes were observed in level $1 \%$ (Tables 4 and 5). The highest seed yield in two bean species in $100 \%$ water requirements and in 2016 and 2017, were 1700 and $1776 \mathrm{~kg} \mathrm{ha}^{-1}$ (Fig. 1). The highest seed yield in 30 and $60 \mathrm{~kg} \mathrm{~N} \mathrm{ha}^{-1}$ fertilizer in 2016 was 1076 and $1173 \mathrm{~kg} \mathrm{ha}^{-1}$ (Fig. 2). The highest seed yield in 30 and $60 \mathrm{~kg} \mathrm{~N} \mathrm{ha}^{-1}$ fertilizers in 2017 were 1107 and $1209 \mathrm{~kg}$ $\mathrm{ha}^{-1}$ (Fig. 3). The interaction between bean crops and fertilizer in normal beans and in $60 \mathrm{~kg} \mathrm{~N} \mathrm{ha}^{-1}$ fertilizer were 2400 and $2512 \mathrm{~kg} \mathrm{ha}^{-1}$ (Fig. 4). The highest seed yield in 2016 and 2017 in $100 \%$ water requirements and $60 \mathrm{~kg} \mathrm{~N} \mathrm{ha}^{-1}$ fertilizers were 2169 and $2253 \mathrm{~kg} \mathrm{ha}^{-1}$ (Fig. 5). The highest seed yield in 2016 and 2017 in $100 \%$ water requirements and $60 \mathrm{~kg} \mathrm{~N} \mathrm{ha}^{-1}$ fertilizers for common bean were 3486 and $3646 \mathrm{~kg} \mathrm{ha}^{-1}$ (Table 6).

Table 4. Mean squares form the combined ANOVA for agronomic traits

\begin{tabular}{|c|c|c|c|c|c|c|c|}
\hline \multirow[t]{2}{*}{ Source } & \multirow[t]{2}{*}{ df } & \multicolumn{2}{|c|}{ Seed yield $\left(\mathrm{kg} \mathrm{ha}^{-1}\right)$} & \multicolumn{2}{|c|}{$\begin{array}{c}\text { 100-seed weight } \\
\text { (g) }\end{array}$} & \multicolumn{2}{|c|}{$\begin{array}{c}\text { Number of pods } \\
\text { per shrub }\end{array}$} \\
\hline & & 2016 & 2017 & 2016 & 2017 & 2016 & 2017 \\
\hline Replication & 2 & $143677^{\mathrm{ns}}$ & $130645^{\mathrm{ns}}$ & $197^{\mathrm{ns}}$ & $190.1^{\mathrm{ns}}$ & $1.57^{\mathrm{ns}}$ & $2.26^{\mathrm{ns}}$ \\
\hline Water requirements & 1 & $2240842^{\text {ns }}$ & $3135651^{\mathrm{ns}}$ & $4067^{*}$ & $3390^{\mathrm{ns}}$ & 19579 & $18984^{\mathrm{ns}}$ \\
\hline Error & 2 & 277146 & 291045 & 173 & 167.6 & 1.91 & 2.09 \\
\hline Nitrogen & 3 & $8182123^{* *}$ & $9159561^{* *}$ & $885^{* *}$ & $880^{* *}$ & 195 & $318.6^{* *}$ \\
\hline Water requirements $\times$ nitrogen & 3 & $3206147^{* *}$ & $3390614^{* *}$ & $702.8^{*}$ & 556 & $20.6^{* *}$ & $5.41^{* *}$ \\
\hline Varieties & 3 & $855459^{* *}$ & $924025^{* *}$ & $37.29^{*}$ & 35.26 & $16.1^{* *}$ & $16.9^{* *}$ \\
\hline Water requirements $\times$ varieties & 3 & $136747^{*}$ & $159486^{*}$ & 70.49 & $68.3^{* *}$ & $7.68^{* *}$ & $9.91^{* *}$ \\
\hline Nitrogen $\times$ varieties & 9 & $389196^{* *}$ & $425595^{* *}$ & $64.94^{* *}$ & $66.1^{* *}$ & $5.32^{* *}$ & $7.02^{* *}$ \\
\hline Water requirements $\times$ nitrogen $\times$ varieties & 9 & $199775^{* *}$ & $213990^{* *}$ & $31.46^{* *}$ & $31.2^{*}$ & $3.14^{* *}$ & $2.74^{* *}$ \\
\hline Error & 60 & 41673 & 42530 & 12.72 & 13.58 & 0.562 & 0.699 \\
\hline $\mathrm{CV}(\%)$ & & 12.4 & 12.6 & 12.1 & 12.8 & 2.19 & 3.32 \\
\hline
\end{tabular}

ns $=$ non-significant; ${ }^{*}$ and ${ }^{* *}=$ significant at $5 \%$ and $1 \%$ probability level, respectively

Table 5. Mean squares form the combined ANOVA for agronomic traits

\begin{tabular}{|c|c|c|c|c|c|}
\hline \multirow[t]{2}{*}{ Source } & \multirow[t]{2}{*}{ df } & \multicolumn{2}{|c|}{ Plant height (cm) } & \multicolumn{2}{|c|}{$\begin{array}{l}\text { Water productivity on seed } \\
\text { yield }\left(\mathrm{kg} \mathrm{m}^{-3}\right)\end{array}$} \\
\hline & & 2016 & 2017 & 2016 & 2017 \\
\hline Replication & 2 & $3082.4^{\mathrm{ns}}$ & $2986.1^{\mathrm{ns}}$ & $0.013^{\mathrm{ns}}$ & $0.010^{\mathrm{ns}}$ \\
\hline Water requirements & 1 & $56654^{*}$ & $56197.4^{*}$ & $0.008^{\mathrm{ns}}$ & $0.038^{\mathrm{ns}}$ \\
\hline Error & 2 & 2884.9 & 2731.9 & 0.024 & 0.020 \\
\hline Nitrogen & 3 & $2661.9^{* *}$ & $3768.6^{* *}$ & $0.15^{* *}$ & $0.158^{* *}$ \\
\hline Water requirements $\times$ nitrogen & 3 & $403.23^{* *}$ & $98.09^{* *}$ & $0.205^{* *}$ & $0.184^{* *}$ \\
\hline Varieties & 3 & $232.01^{* * *}$ & $204.33^{* *}$ & $0.051^{* *}$ & $0.046^{* *}$ \\
\hline Water requirements varieties & 3 & $116.64^{* *}$ & $122.59^{* *}$ & $0.003^{\text {ns }}$ & $0.004^{\mathrm{ns}}$ \\
\hline Nitrogen $\times$ varieties & 9 & $55.21^{* *}$ & $64.85^{* *}$ & $0.015^{* *}$ & $0.014^{* *}$ \\
\hline Water requirements $\times$ nitrogen $\times$ varieties & 9 & $51.78^{* *}$ & $52.77^{* *}$ & $0.010^{* *}$ & $0.010^{* *}$ \\
\hline Error & 60 & 6.92 & 7.51 & 0.002 & 0.002 \\
\hline $\mathrm{CV}(\%)$ & & & 3.93 & 6.7 & 6.6 \\
\hline
\end{tabular}

ns $=$ non-significant; ${ }^{*}$ and ${ }^{* *}=$ significant at $5 \%$ and $1 \%$ probability level, respectively 


$$
-3117 \text { - }
$$

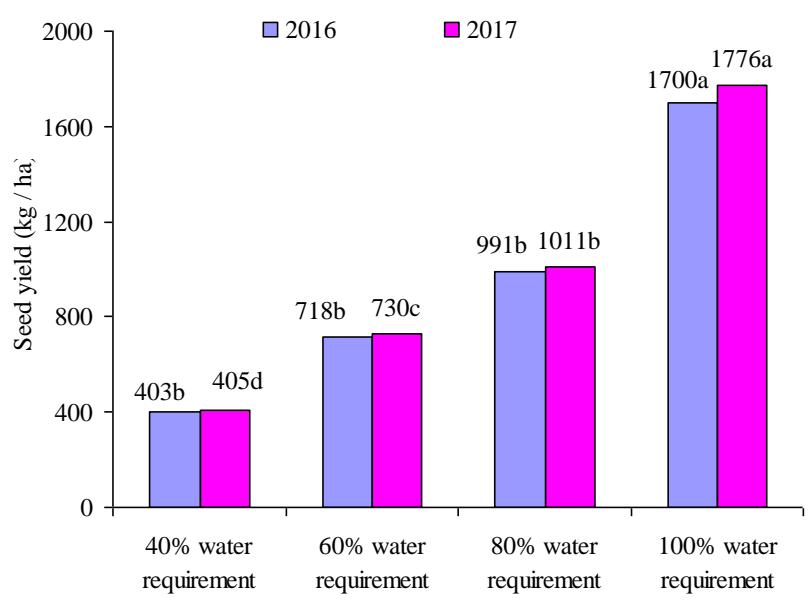

Figure 1. Effect of irrigation on seed yield in bean cultivars in 2016 and 2017

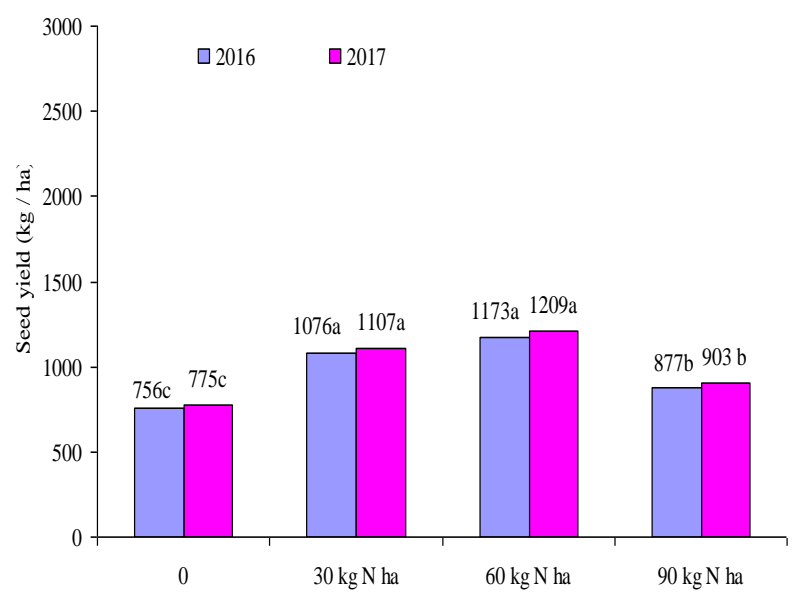

Figure 2. Effect of nitrogen on seed yield in bean cultivars in 2016 and 2017

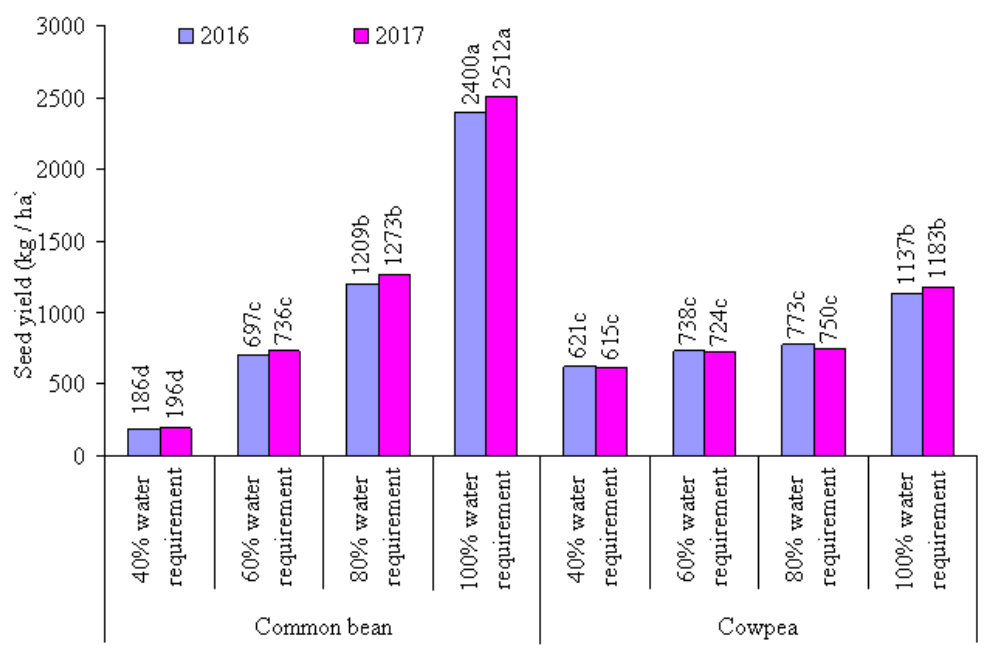

Figure 3. Interaction of bean cultivars and irrigation on seed yield in bean cultivars in 2016 and 2017 


$$
-3118-
$$

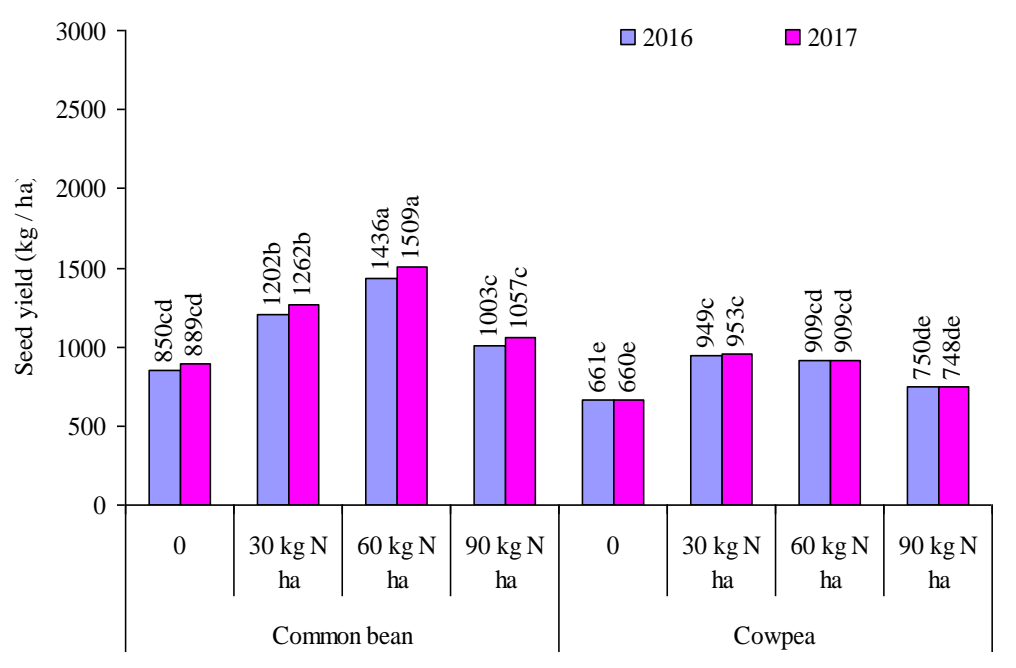

Figure 4. Interaction of nitrogen and cultivars on seed yield in 2016 and 2017

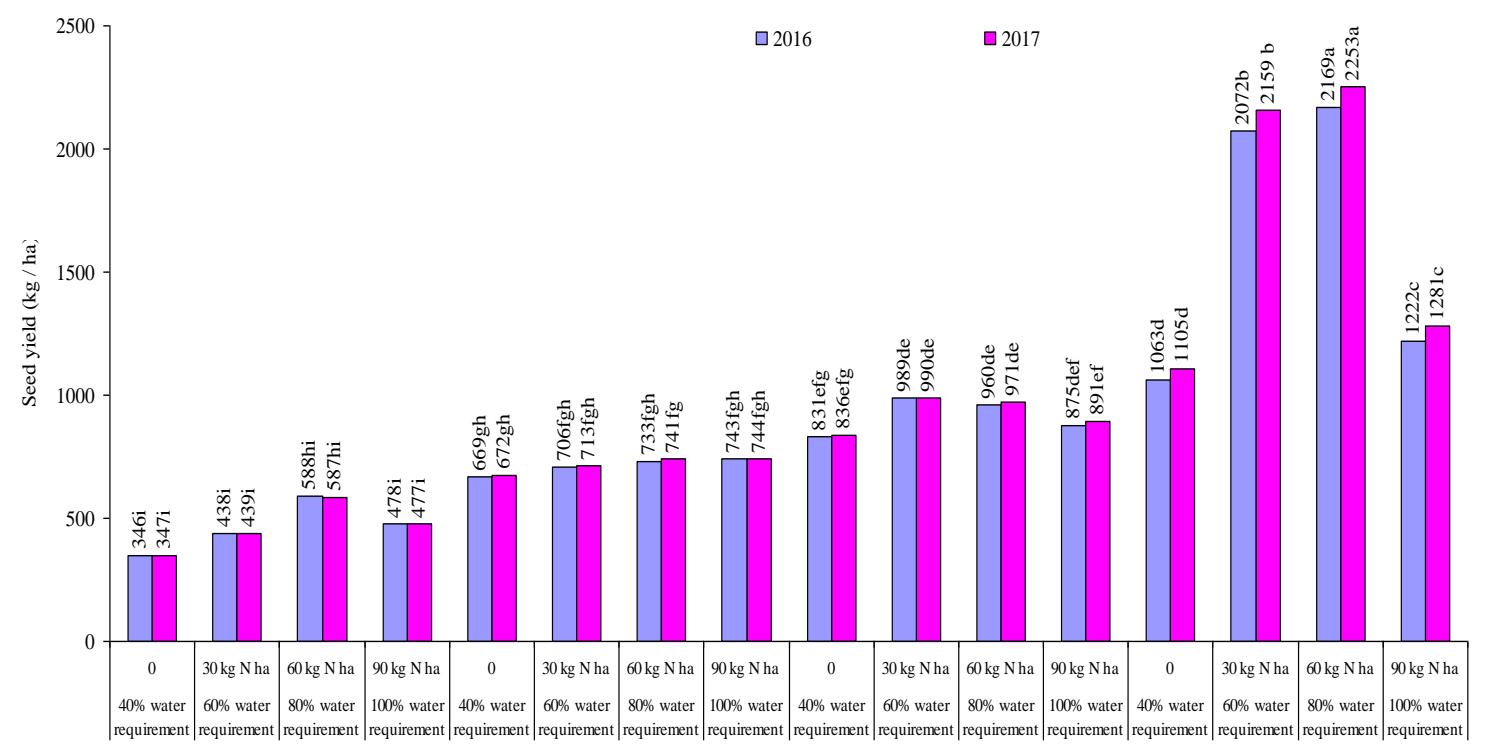

Figure 5. Interaction of nitrogen fertilizer and irrigation on seed yield in 2016 and 2017

\section{Weight of 100 seeds}

The total weight of 100 seeds in 2016 and 2017 were significant in 5\% and other variables were significant in 1\% (Table 4). The weight of 100 seeds in 2016 and 2017 were 34.7 and $36.1 \mathrm{~g}$ (Fig. 6). The highest weight of 100 seeds in $100 \%$ water requirement were 37.4 and $36.7 \mathrm{~g}$ in 2016 and 2017 (Fig. 7). The highest weight of 100 seeds in 2016 and 2017 with 100\% water requirement were normal (Fig. 8). The highest weight of 100 seeds in 2016 and 2017 in $60 \mathrm{~kg} \mathrm{~N} \mathrm{ha}^{-1}$ fertilizer were 31.1 and $30.2 \mathrm{~g}$ (Fig. 9). The highest Weight of 100 seeds, considering species and Nitrogen fertilizer, in 2016 and 2017 were 40.2 and $36.6 \mathrm{~g}^{\text {in }} 60 \mathrm{~kg} \mathrm{~N} \mathrm{ha}^{-1}$ (Fig. 10). The highest weight of 100 seeds in $100 \%$ water requirement and $60 \mathrm{~kg} \mathrm{~N} \mathrm{ha}^{-1}$ fertilizer in common bean in 2016 and 2017 were 64.2 and $66.7 \mathrm{~g}$ (Table 6). 


$$
\text { - } 3119 \text { - }
$$

Table 6. Mean squares form the combined ANOVA for agronomic traits

\begin{tabular}{|c|c|c|c|c|c|c|c|c|c|c|c|c|}
\hline \multicolumn{2}{|c|}{$\mathrm{WP}\left(\mathrm{kg} \mathrm{m}^{-3}\right)$} & \multicolumn{2}{|c|}{$\begin{array}{l}\text { Number of } \\
\text { pods per } \\
\text { plant }\end{array}$} & \multicolumn{2}{|c|}{ Plant height (cm) } & \multicolumn{2}{|c|}{$\begin{array}{l}\text { Weight of } 100 \\
\text { seed (g) }\end{array}$} & \multicolumn{2}{|c|}{$\begin{array}{l}\text { Seed yield } \\
(\mathrm{kg} / \mathrm{ha})\end{array}$} & \multirow[t]{2}{*}{$\begin{array}{r}\text { Nitrogen } \\
\left(\mathbf{k g ~ h a}^{-1}\right)\end{array}$} & \multirow{2}{*}{\multicolumn{2}{|c|}{$\begin{array}{c}\text { Water } \\
\text { requirement } \\
(\%)\end{array}$}} \\
\hline 2017 & 2016 & 2017 & 2016 & 2017 & 2016 & 2017 & 2016 & 2017 & 2016 & & & \\
\hline 0.060 & 0.061 & $8 \mathrm{~s}$ & $7 \mathrm{r}$ & $32.8 \mathrm{q}$ & $37.1 \mathrm{p}$ & $31.5 \mathrm{~d}$ & $32.2 \mathrm{~d}$ & 1551 & $146 \mathrm{j}$ & 0 & & \\
\hline $0.08 \mathrm{o}$ & 0.081 & $8 \mathrm{qrs}$ & $8 \mathrm{pqr}$ & $37.0 \mathrm{opq}$ & 38.9 op & $27.3 \mathrm{~d}-\mathrm{j}$ & $28.1 \mathrm{~d}-\mathrm{h}$ & 2051 & $195 j$ & 30 & & \\
\hline 0.08 no & 0.081 & $8 \mathrm{rs}$ & $8 \mathrm{qr}$ & $36.0 \mathrm{pq}$ & $38.5 \mathrm{op}$ & $31.3 \mathrm{de}$ & $32.0 \mathrm{~d}$ & 2041 & $193 j$ & 60 & & \\
\hline 0.08 no & 0.091 & $8 \mathrm{qrs}$ & $8 \mathrm{qr}$ & 37.3opq & 39.0op & 26.1d-k & $27.1 \mathrm{~d}-\mathrm{i}$ & 2181 & $209 j$ & 90 & & \\
\hline $0.19 \mathrm{j}-\mathrm{m}$ & $0.20 \mathrm{jk}$ & 8pqrs & $8 n-r$ & $38.3 n-q$ & 40.6nop & 29.9def & $31.3 \mathrm{def}$ & 670ijk & 635hi & 0 & & \\
\hline $0.22 \mathrm{~h}-\mathrm{m}$ & $0.22 \mathrm{~h}-\mathrm{k}$ & 9opqr & $9 m-q$ & $39.5 m-p$ & $41.8 \mathrm{mno}$ & $28.8 \mathrm{~d}-\mathrm{g}$ & $29.9 \mathrm{def}$ & $758 \mathrm{ijk}$ & 718hi & 30 & & \\
\hline $0.23 \mathrm{~g}-1$ & $0.23 \mathrm{~g}-\mathrm{k}$ & 9op-s & $8 \mathrm{~m}-\mathrm{r}$ & $39.3 m-p$ & 42.01-o & 29.6def & $31.3 \mathrm{def}$ & $800 \mathrm{ij}$ & $753 \mathrm{hi}$ & 60 & & 茪 \\
\hline $0.20 \mathrm{i}-\mathrm{m}$ & $0.21 \mathrm{~h}-\mathrm{k}$ & 9opqr & $8 \mathrm{~m}-\mathrm{r}$ & $40.5 \mathrm{mno}$ & 42.61-o & 28.0d-h & $29.0 \mathrm{~d}-\mathrm{g}$ & $715 \mathrm{ijk}$ & $683 \mathrm{hi}$ & 90 & & 0 \\
\hline $0.27 \mathrm{e}-\mathrm{i}$ & $0.27 \mathrm{fgh}$ & 9opq & 91-p & $42.4 \mathrm{mn}$ & $44.11 \mathrm{mn}$ & 29.4def & $30.4 \mathrm{def}$ & 1170fgh & $1125 \mathrm{fg}$ & 0 & & \\
\hline $0.30 \mathrm{~d}-\mathrm{g}$ & 0.30 efg & 10nop & $9 \mathrm{k}-\mathrm{o}$ & $42.6 \mathrm{mn}$ & $44.71 \mathrm{mn}$ & $30.6 \mathrm{de}$ & 31.6de & $1299 \mathrm{ef}$ & $1240 \mathrm{ef}$ & 30 & & \\
\hline $0.31 \mathrm{c}-\mathrm{f}$ & $0.32 \mathrm{def}$ & 10nop & $9 \mathrm{k}-\mathrm{n}$ & $42.9 \mathrm{~m}$ & $45.51 \mathrm{~m}$ & 29.4def & 30.6 def & $1385 \mathrm{def}$ & 1313def & 60 & & \\
\hline $0.28 \mathrm{~d}-\mathrm{h}$ & $0.28 \mathrm{fgh}$ & $10 \mathrm{mno}$ & 9k-n & $43.0 \mathrm{~m}$ & 46.21 & 29.4def & $30.7 \mathrm{def}$ & $1237 \mathrm{efg}$ & $1156 \mathrm{fg}$ & 90 & & \\
\hline $0.29 \mathrm{~d}-\mathrm{g}$ & 0.30 efg & 12hij & $11 \mathrm{hi}$ & 60.01 & $62.6 \mathrm{k}$ & $43.2 \mathrm{c}$ & $45.7 \mathrm{c}$ & 1561de & 1495de & 0 & & \\
\hline $0.52 \mathrm{~b}$ & $0.54 b$ & $12 \mathrm{hij}$ & 11hi & & & & & $2784 b$ & $2657 b$ & 30 & & \\
\hline $0.69 a$ & $0.70 \mathrm{a}$ & $15 \mathrm{c}$ & $14 \mathrm{~cd}$ & $75.2 \mathrm{jk}$ & $78.9 \mathrm{i}$ & $64.2 \mathrm{a}$ & $66.7 \mathrm{a}$ & $3646 a$ & $3486 a$ & 60 & & \\
\hline $0.39 \mathrm{c}$ & $0.40 \mathrm{c}$ & 13ghi & $12 \mathrm{gh}$ & 60.11 & $63.3 \mathrm{k}$ & $47.1 \mathrm{bc}$ & $48.6 \mathrm{bc}$ & $2058 \mathrm{c}$ & $1963 c$ & 90 & & \\
\hline $0.19 \mathrm{klm}$ & $0.21 \mathrm{~h}-\mathrm{k}$ & $8 \mathrm{qrs}$ & 8o-r & $71.3 \mathrm{k}$ & $72.7 \mathrm{j}$ & $25.8 \mathrm{~d}-1$ & $26.0 e-j$ & $457 \mathrm{kl}$ & $462 \mathrm{ij}$ & 0 & & \\
\hline $0.23 \mathrm{~g}-1$ & $0.27 f-i$ & $10 \mathrm{mno}$ & $9 \mathrm{klm}$ & $88.6 \mathrm{gh}$ & $91.8 \mathrm{fg}$ & $19.3 \mathrm{~m}$ & $19.7 \mathrm{k}$ & $573 \mathrm{jk}$ & 579hi & 30 & & \\
\hline $0.34 \mathrm{~cd}$ & $0.38 \mathrm{~cd}$ & $11 \mathrm{klm}$ & $10 \mathrm{jk}$ & $84.1 \mathrm{i}$ & $88.5 \mathrm{~g}$ & $21.1 \mathrm{klm}$ & $21.7 \mathrm{ijk}$ & $825 \mathrm{ij}$ & $834 \mathrm{gh}$ & 60 & & \\
\hline $0.25 \mathrm{f}-\mathrm{k}$ & $0.28 \mathrm{fgh}$ & $101 \mathrm{mn}$ & $10 \mathrm{kl}$ & $77.8 \mathrm{j}$ & $83.2 \mathrm{~h}$ & 22.8h-m & $23.7 \mathrm{~g}-\mathrm{k}$ & 604ijk & 610hi & 90 & & \\
\hline $0.21 \mathrm{i}-\mathrm{m}$ & $0.24 \mathrm{~g}-\mathrm{k}$ & $11 \mathrm{jkl}$ & 11ij & $88.8 \mathrm{~g}$ & 91.0fg & $25.4 \mathrm{e}-1$ & $25.7 f-j$ & 683ijk & 697hi & 0 & & \\
\hline $0.23 \mathrm{~g}-1$ & $0.26 \mathrm{f}-\mathrm{j}$ & $12 \mathrm{ijk}$ & $11 \mathrm{hij}$ & $92.4 \mathrm{fg}$ & $96.2 \mathrm{de}$ & $20.4 \mathrm{klm}$ & $20.8 \mathrm{jk}$ & 739ijk & 754hi & 30 & & \\
\hline $0.22 \mathrm{~h}-\mathrm{m}$ & $0.25 f-j$ & $12 g-j$ & 12ghi & $89.5 \mathrm{~g}$ & $94.8 \mathrm{ef}$ & $21.1 \mathrm{klm}$ & $21.7 \mathrm{ijk}$ & 713ijk & 728hi & 60 & & \\
\hline $0.23 \mathrm{~g}-1$ & $0.26 \mathrm{f}-\mathrm{i}$ & $12 \mathrm{hij}$ & 12ghi & 84.1hi & $90.4 \mathrm{~g}$ & 21.8i-m & $22.7 \mathrm{~h}-\mathrm{k}$ & 760ijk & 775hi & 90 & & $\stackrel{5}{2}$ \\
\hline $0.15 \mathrm{mn}$ & $0.17 \mathrm{k}$ & 14cde & $14 \mathrm{de}$ & $98.3 \mathrm{de}$ & $101.4 \mathrm{c}$ & $20.7 \mathrm{klm}$ & $20.9 \mathrm{jk}$ & 625ijk & 644hi & 0 & & 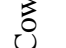 \\
\hline $0.21 \mathrm{i}-\mathrm{m}$ & $0.24 \mathrm{~g}-\mathrm{k}$ & 14def & 14def & $97.0 \mathrm{de}$ & $101.6 \mathrm{c}$ & $27.4 d-i$ & $27.9 \mathrm{~d}-\mathrm{h}$ & 857hij & $884 \mathrm{gh}$ & 30 & & \\
\hline $0.19 \mathrm{i}-\mathrm{m}$ & $0.22 \mathrm{~h}-\mathrm{k}$ & $13 \mathrm{efg}$ & $13 \mathrm{fg}$ & 95.8def & $101.9 \mathrm{c}$ & $20.4 \mathrm{klm}$ & $21.1 \mathrm{jk}$ & $802 \mathrm{ij}$ & $827 \mathrm{gh}$ & 60 & & \\
\hline $0.171 \mathrm{~m}$ & $0.20 \mathrm{ijk}$ & $13 \mathrm{efg}$ & $13 \mathrm{fg}$ & 94.0ef & $101.7 \mathrm{c}$ & $20.21 \mathrm{~m}$ & $21.0 \mathrm{jk}$ & 714ijk & 736hi & 90 & & \\
\hline $0.18 \mathrm{klm}$ & $0.19 \mathrm{jk}$ & 13fgh & $13 \mathrm{ef}$ & $98.2 d$ & $95.3 \mathrm{ef}$ & $21.5 \mathrm{j}-\mathrm{m}$ & $21.2 \mathrm{jk}$ & 875hij & $841 \mathrm{gh}$ & 0 & & \\
\hline $0.33 \mathrm{cde}$ & $0.35 \mathrm{cde}$ & $19 a$ & $20 \mathrm{a}$ & $122.3 \mathrm{a}$ & 116.5a & 30.0def & 29.4def & $1643 d$ & $1580 \mathrm{~d}$ & 30 & & \\
\hline $0.26 \mathrm{e}-\mathrm{j}$ & $0.28 \mathrm{fgh}$ & $17 b$ & $18 \mathrm{~b}$ & $113.2 b$ & $106.3 b$ & $24.2 \mathrm{f}-\mathrm{m}$ & $23.5 \mathrm{~g}-\mathrm{k}$ & $1296 \mathrm{ef}$ & $1246 \mathrm{ef}$ & 60 & & \\
\hline $0.18 \mathrm{klm}$ & $0.20 \mathrm{ijk}$ & $15 \mathrm{~cd}$ & $15 \mathrm{c}$ & $108.3 \mathrm{c}$ & $100.3 \mathrm{~cd}$ & 23.0g-m & $22.2 \mathrm{ijk}$ & 916ghi & $881 \mathrm{gh}$ & 90 & & \\
\hline
\end{tabular}

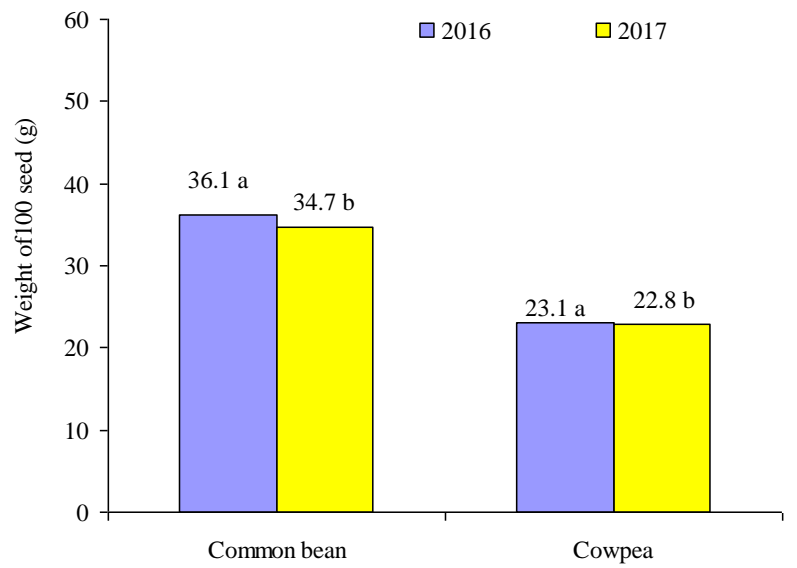

Figure 6. Weight of 100 seed in bean cultivars in 2016 and 2017 


$$
-3120-
$$

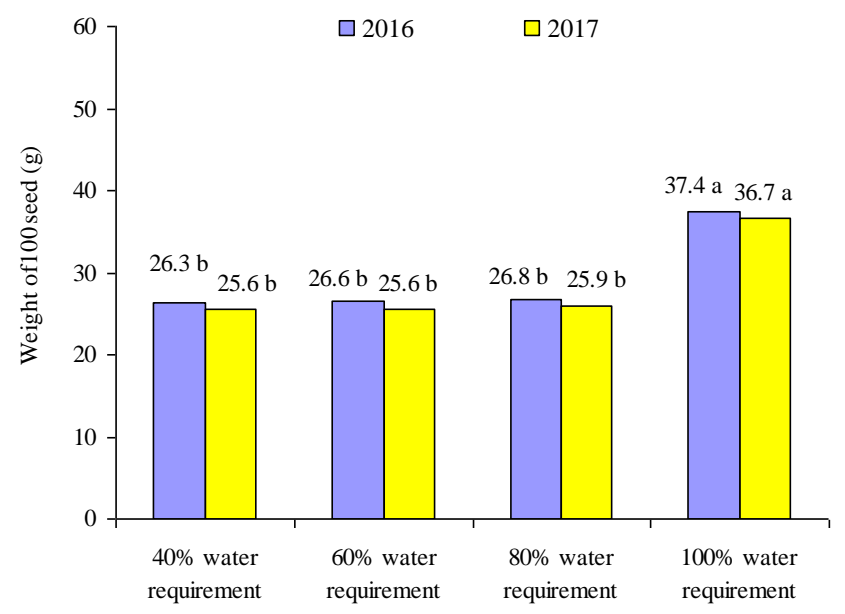

Figure 7. Effect of irrigation on weight of 100 seed cultivars in 2016 and 2017

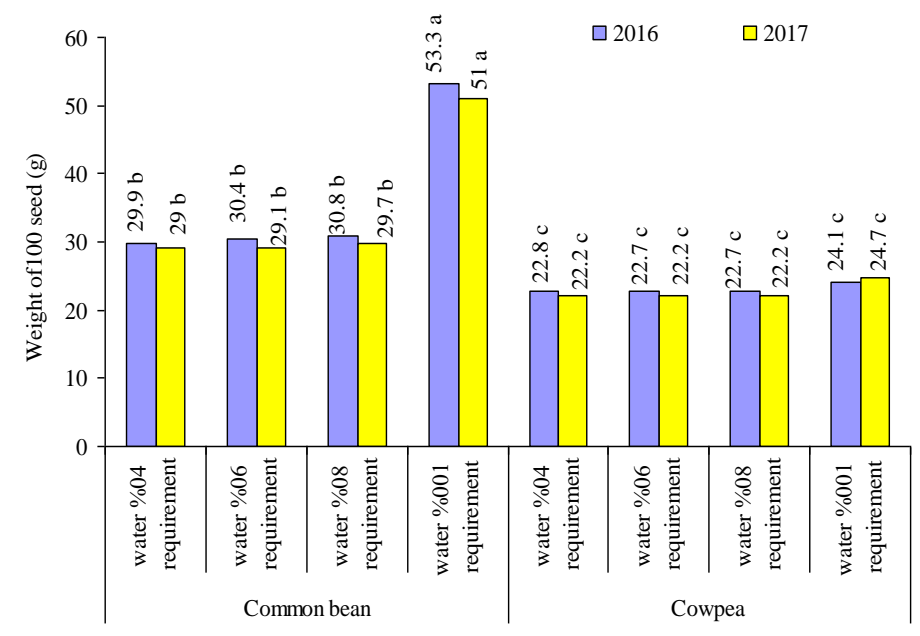

Figure 8. Interaction of nitrogen and cultivars on weight of 100 seed in 2016 and 2017

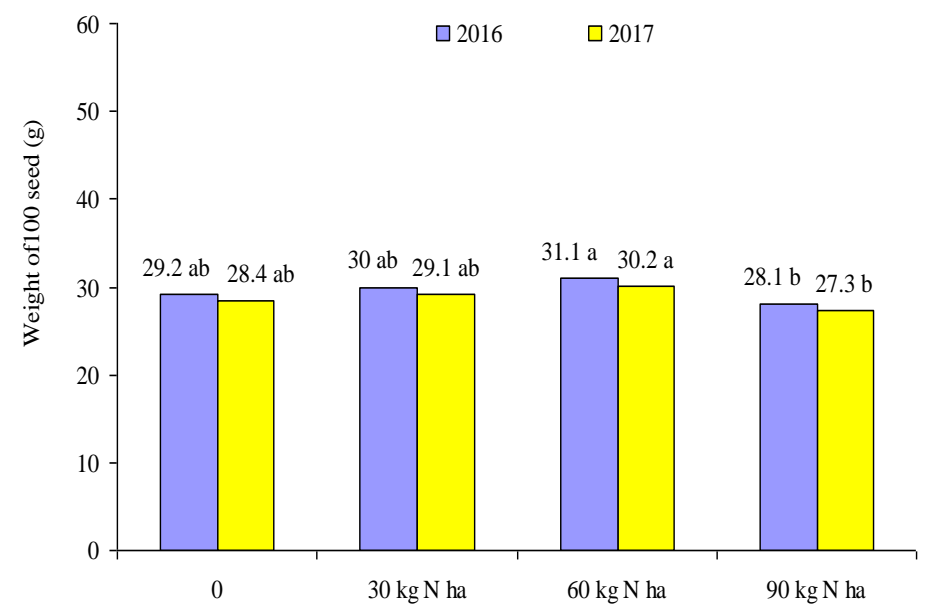

Figure 9. Effect of nitrogen on weight of 100 seed in bean. cultivars in 2016 and 2017 


$$
-3121-
$$

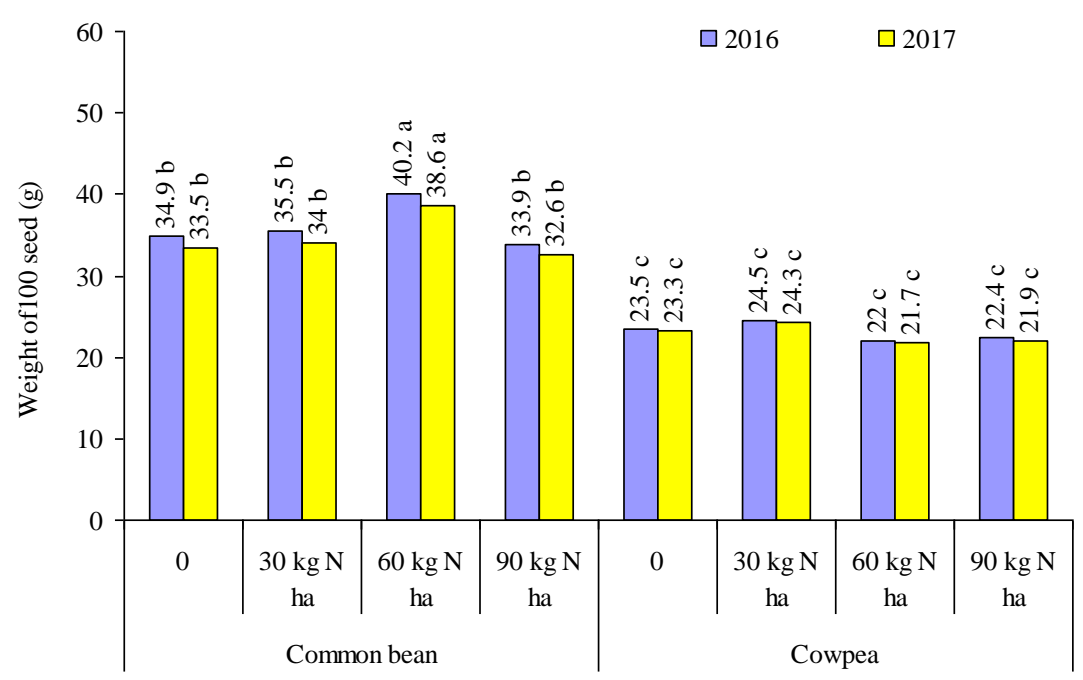

Figure 10. Interaction of nitrogen fertilizer and cultivars on weight of 100 seed in 2016 and 2017

\section{Number of pods per plant}

The effect of varieties was not significant during two years but in other references it was $1 \%$ (Table 4). The highest Number of pods per plant varieties in $100 \%$ water requirement in 2016 and 2017 were 31 and 32 (Fig. 11). The highest number of pods in 2016 and 2017, in 100\% water requirement for Cowpea were 43 and 45 (Fig. 12). The highest number of pods in 2016 and 2017, in $30 \mathrm{~kg} \mathrm{~N} \mathrm{ha}^{-1}$ were 27 and 26 (Fig. 13). The highest number of pods in reaction of varieties and Nitrogen fertilizer in 2016 and 2017 were 42 and 41 in Cowpea and in $30 \mathrm{~kg} \mathrm{~N} \mathrm{ha}^{-1}$ (Fig. 14). The highest number of pods in 2016, in $60 \%$ and $80 \%$ water requirement and 30 and $60 \mathrm{~kg} \mathrm{~N} \mathrm{ha}^{-1}$ were 36 and 35 (Fig. 15). The highest number of pods in 2017, in $60 \%$ and $80 \%$ water requirement and 30 and $60 \mathrm{~kg} \mathrm{~N} \mathrm{ha}^{-1}$ in Cowpea were 37 and 36 (Fig. 15).

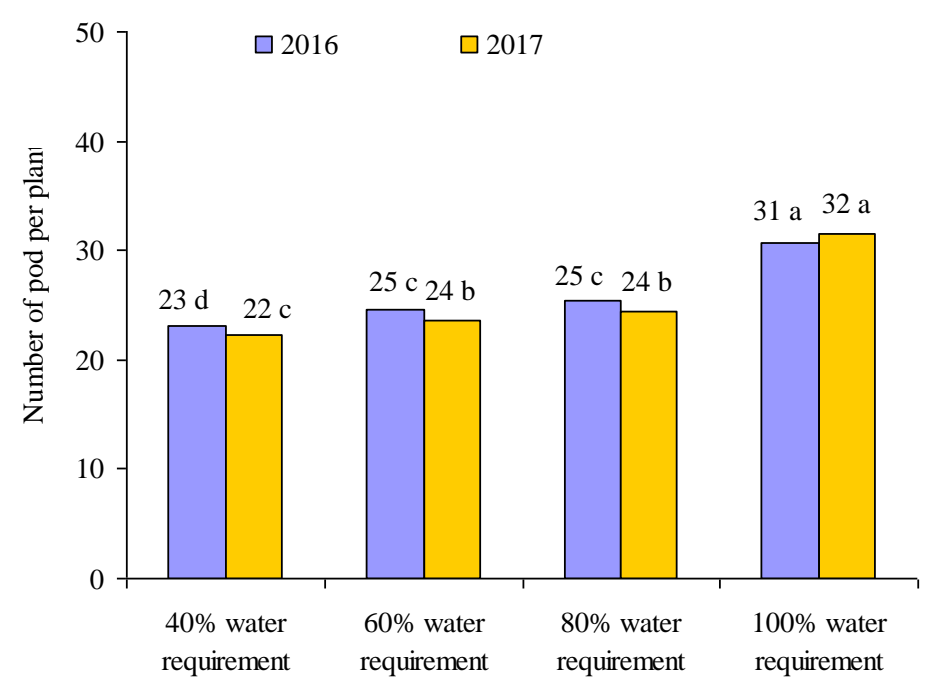

Figure 11. Effect of irrigation on number of pods per plant in bean 


$$
-3122-
$$

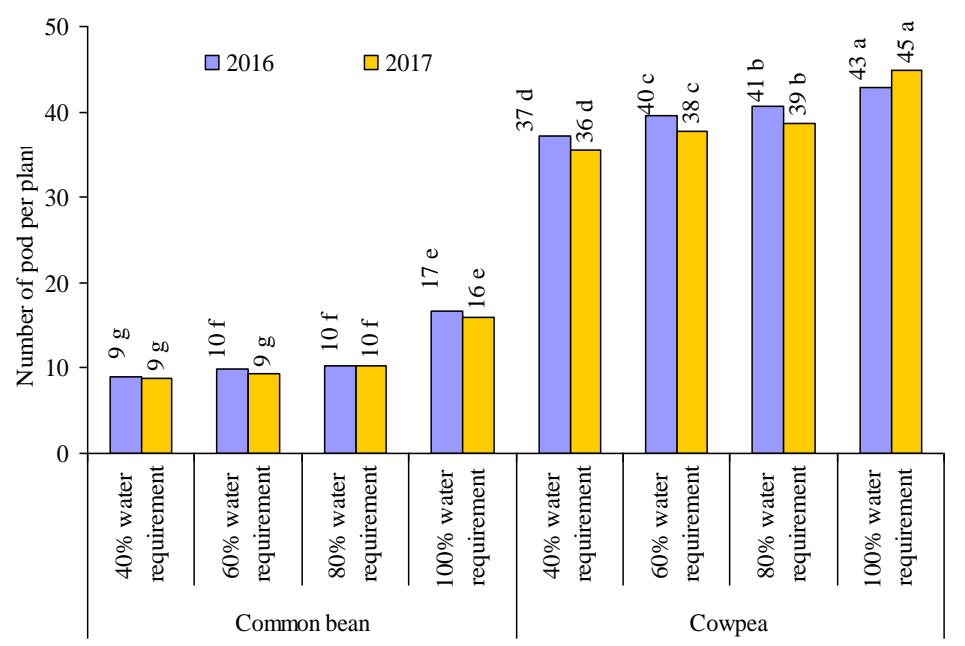

Figure 12. Interaction of irrigation and cultivars on number of pods per plant in 2016 and 2017

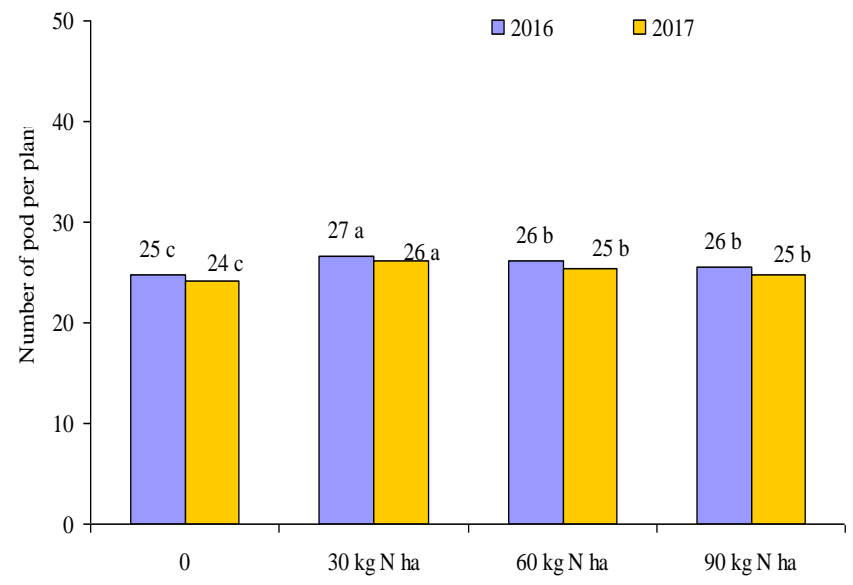

Figure 13. Effect of nitrogen fertilizer on number of pods per plant in bean

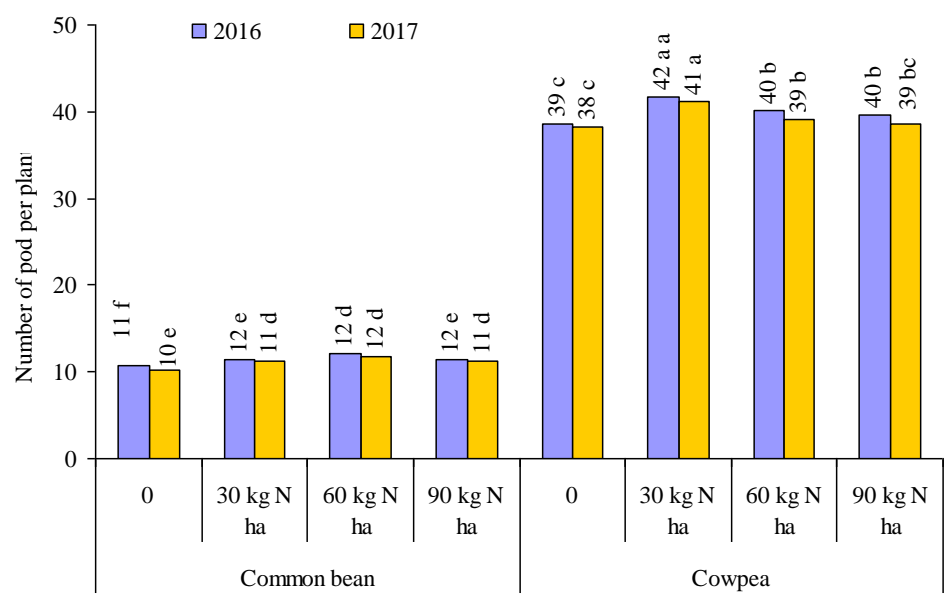

Figure 14. Interaction of nitrogen fertilizer and cultivars on number of pods per plant in 2016 and 2017 


$$
-3123-
$$

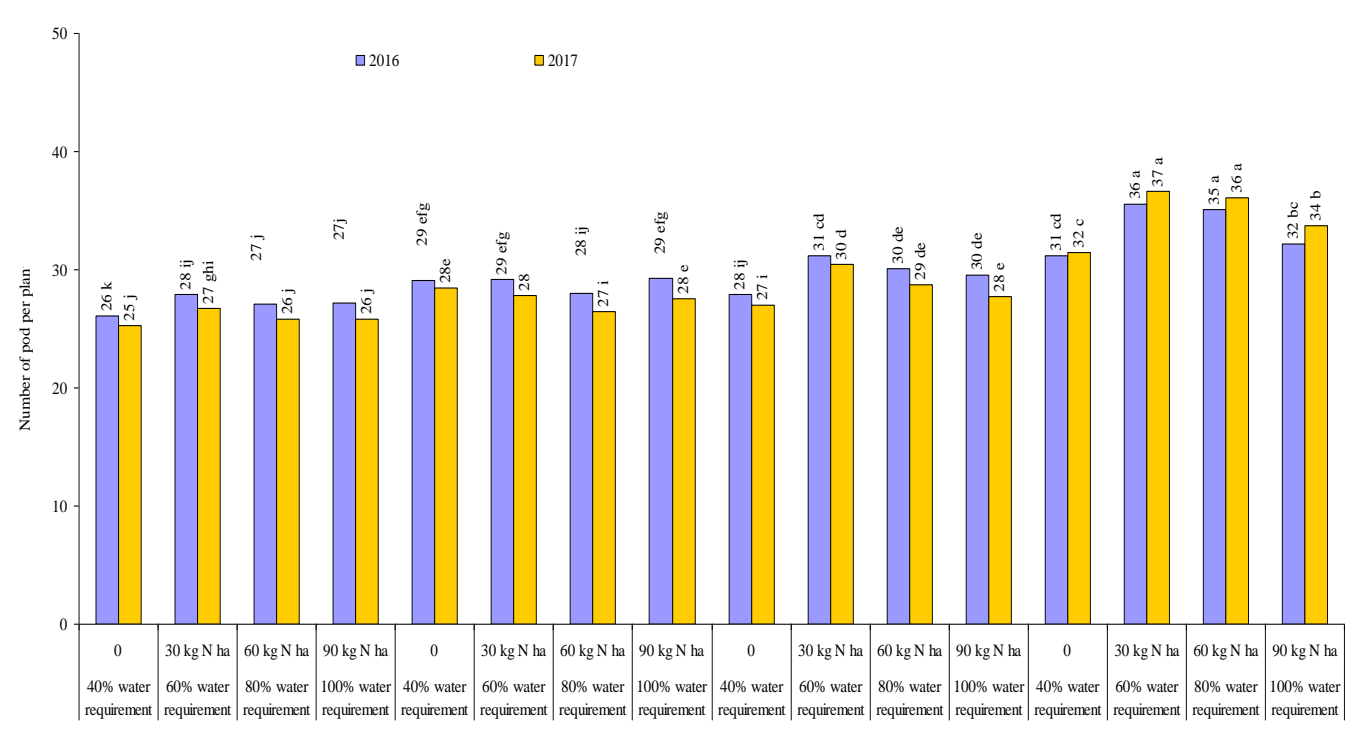

Figure 15. Interaction of nitrogen fertilizer and irrigation on number of pods per plant in 2016 and 2017

\section{Plant height}

Plant height was significant during 2 years in $5 \%$ and other changes were significant in 1\% (Table 5). The maximum height of Cowpea plant in 2016 and 2017 were 95.8 and $94 \mathrm{~cm}$ (Fig. 16). The maximum Plant height in bean varieties in $100 \%$ water requirement were 87 and $88.9 \mathrm{~cm}$ in 2016 and 2017 (Fig. 17). Maximum plant height in bean varieties in $100 \%$ water requirement and Cowpea varieties were 104.6 and $110.6 \mathrm{~cm}$ in 2016 and 2017 (Fig. 18). The maximum plant height in 2016 in 30 and 60 $\mathrm{kg} \mathrm{N} \mathrm{ha}{ }^{-1}$ was $74.5 \mathrm{~cm}$ (Fig. 19). The maximum plant height in 2016 in 30 and $60 \mathrm{~kg} \mathrm{~N} \mathrm{ha}^{-1}$ fertilizer were 72 and $72.5 \mathrm{~cm}$ (Fig. 19). Maximum Plant height in relations of varieties and Nitrogen fertilizer during 2 years in $30 \mathrm{~kg} \mathrm{~N}$ ha ${ }^{-1}$ were 101.5 and $100.1 \mathrm{~cm}$ (Fig. 20). Maximum plant height in 2016 in 100\% water requirement and in 30 and $60 \mathrm{~kg} \mathrm{~N}^{-1}$ were 98.2 and $95.7 \mathrm{~cm}$ (Fig. 21). Maximum plant height in 2017 in $100 \%$ water requirement and in 30 and $60 \mathrm{~kg} \mathrm{~N} \mathrm{ha}^{-1}$ fertilizer were 100.9 and $99 \mathrm{~cm}$ (Fig. 21). Maximum plant height in 2016 and 2017 in $100 \%$ water requirement and $30 \mathrm{~kg} \mathrm{~N} \mathrm{ha}{ }^{-1}$ fertilizer were 116.3 and $122.2 \mathrm{~cm}$ for Cowpea (Table 5).

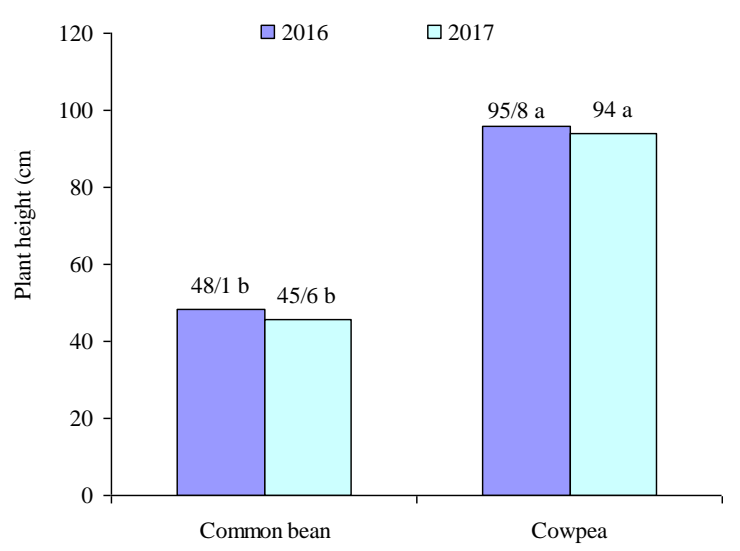

Figure 16. Plant height in bean cultivars in 2016 and 2017 


$$
-3124 \text { - }
$$

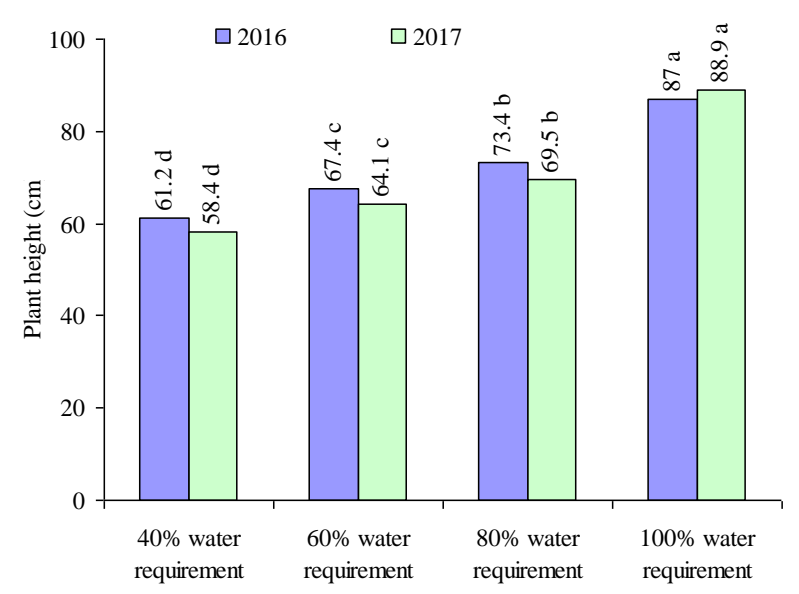

Figure 17. Effect of irrigation on plant height in bean

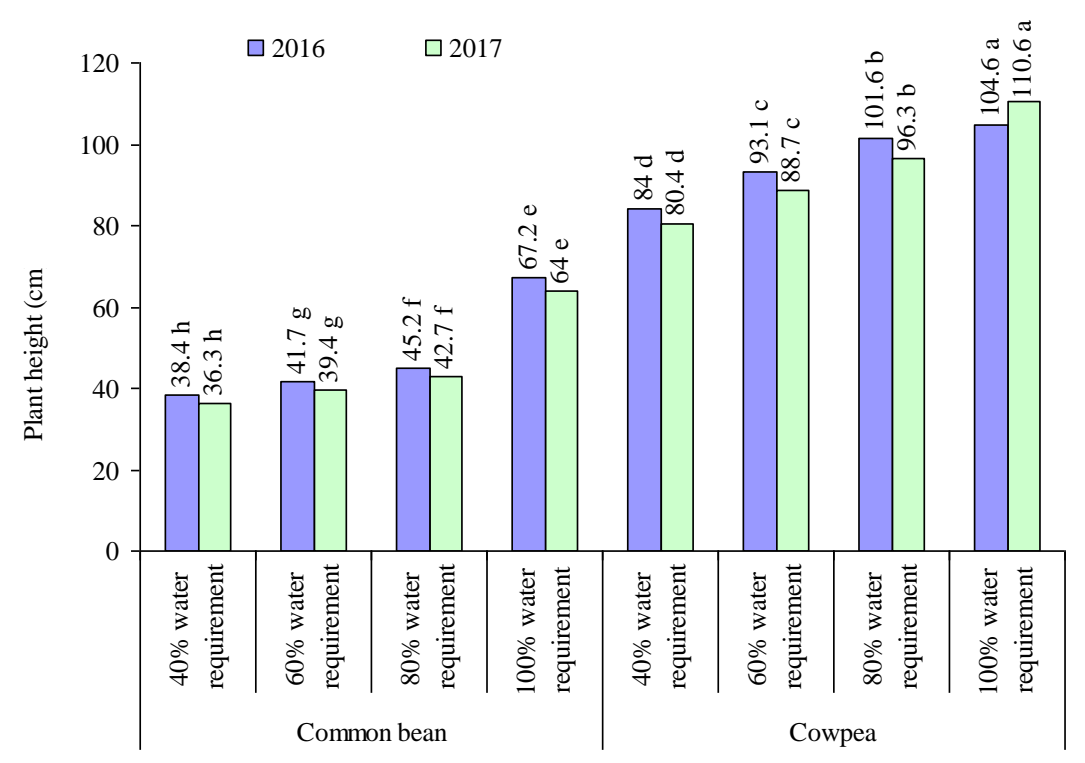

Figure 18. Interaction of irrigation and cultivars on plant height in 2016 and 2017

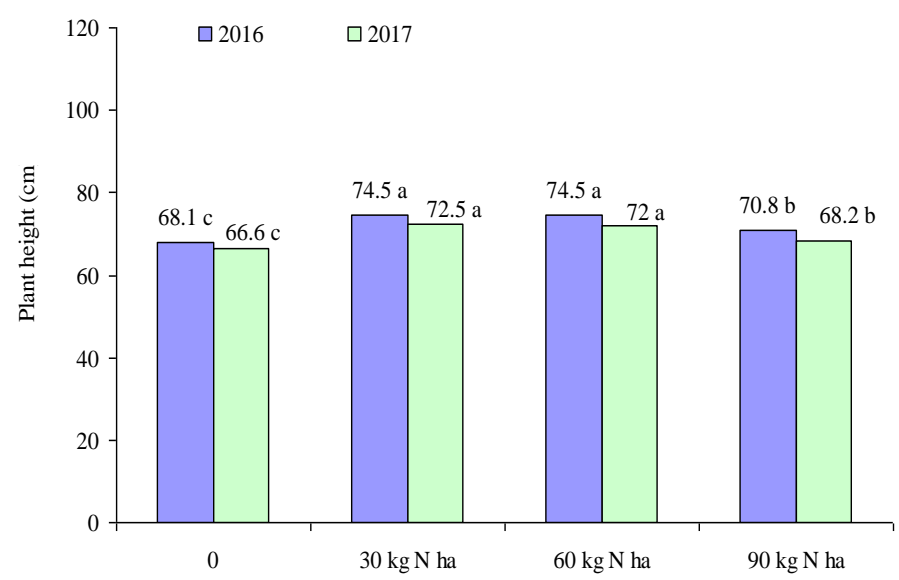

Figure 19. Effect of nitrogen fertilizer on plant height in bean cultivars in 2016 and 2017 


$$
-3125-
$$

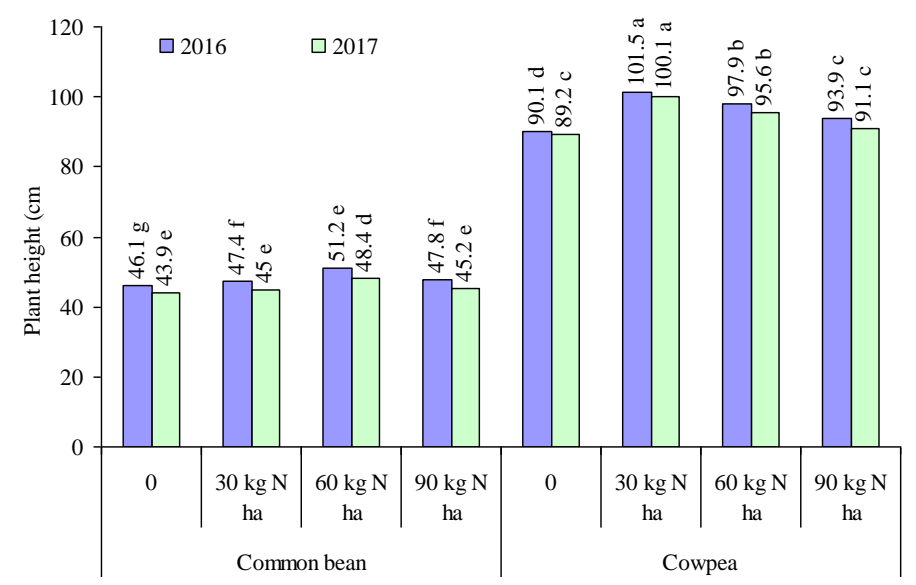

Figure 20. Interaction of nitrogen fertilizer and cultivars on plant height in 2016 and 2017

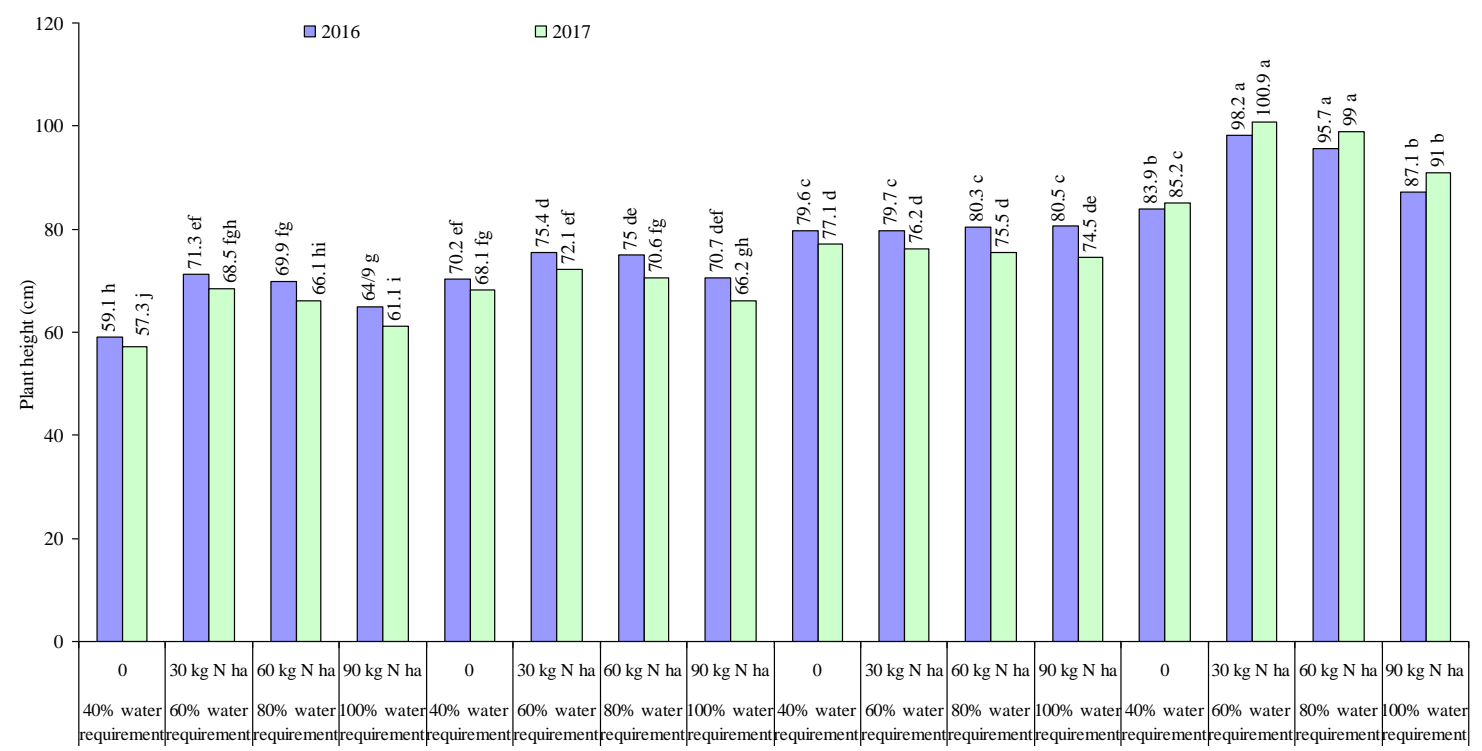

Figure 21. Interaction of nitrogen fertilizer and irrigation on plant height in 2016 and 2017

\section{Water productivity (WP)}

The Water productivity on seed yield regarding to bean varieties and interaction of varieties and fertilizer in 2016 and 2017 were not significant. However, the other sources were significant in $1 \%$ (Table 5). The highest efficiency of water consumption in 2016 and 2017 in $100 \%$ water requirements were 0.36 and $0.34 \mathrm{~kg} \mathrm{~m}^{-3}$ (Fig. 22). The highest efficiency of water consumption in 2016 and 2017 for normal beans in 100\% water requirement were 0.48 and $0.47 \mathrm{~kg} \mathrm{~m}^{-3}$ (Fig. 23). The highest efficiency of water consumption in 2016 and 2017 in $60 \mathrm{~kg} \mathrm{~N} \mathrm{ha}^{-1}$ fertilizer were 0.31 and $0.29 \mathrm{~kg} \mathrm{~m}^{-3}$ (Fig. 24). The highest efficiency of water consumption in 2016 and 2017 was observed in 30 and $60 \mathrm{~kg} \mathrm{~N} \mathrm{ha}^{-1}$ fertilizer and $100 \%$ water requirement (Fig. 25). The highest Water productivity in 2016 and 2017 was observed in common bean, 100\% water requirement and $60 \mathrm{~kg} \mathrm{~N} \mathrm{ha}^{-1}$ fertilizer (Table 6). 


$$
\text { - } 3126-
$$

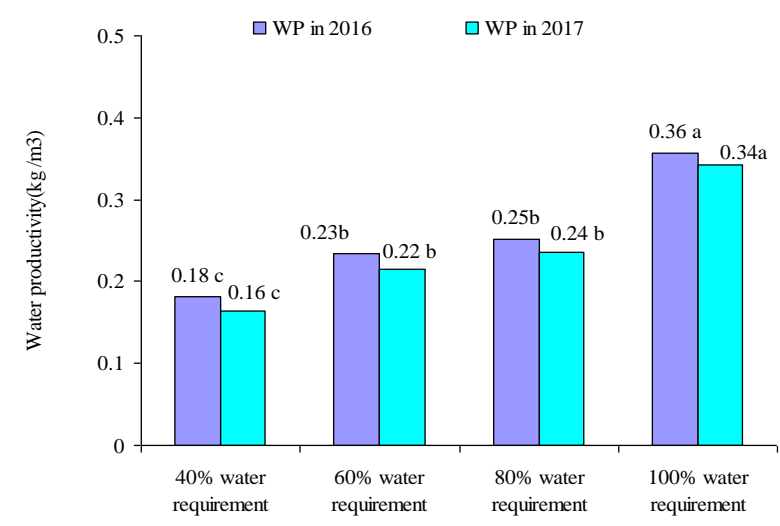

Figure 22. Effect of irrigation on WP in 2016 and 2017

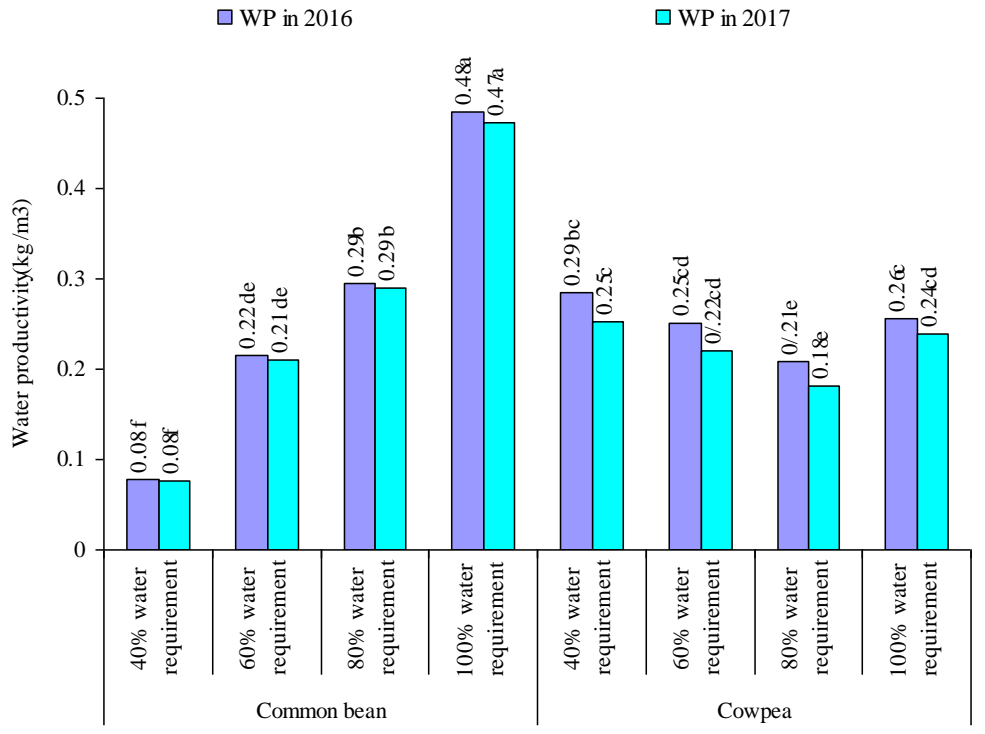

Figure 23. Interaction of irrigation and cultivars on WP in 2016 and 2017

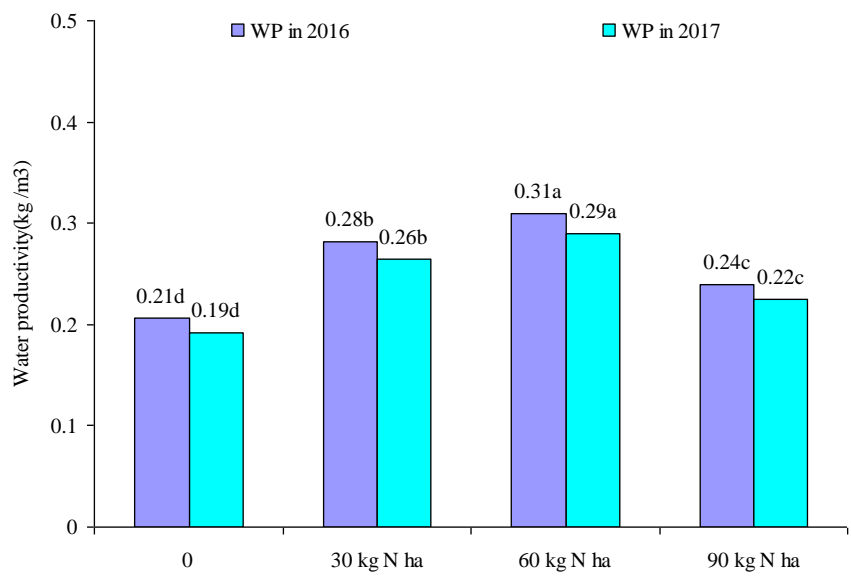

Figure 24. Effect of nitrogen fertilizer on WP in 2016 and 2017 


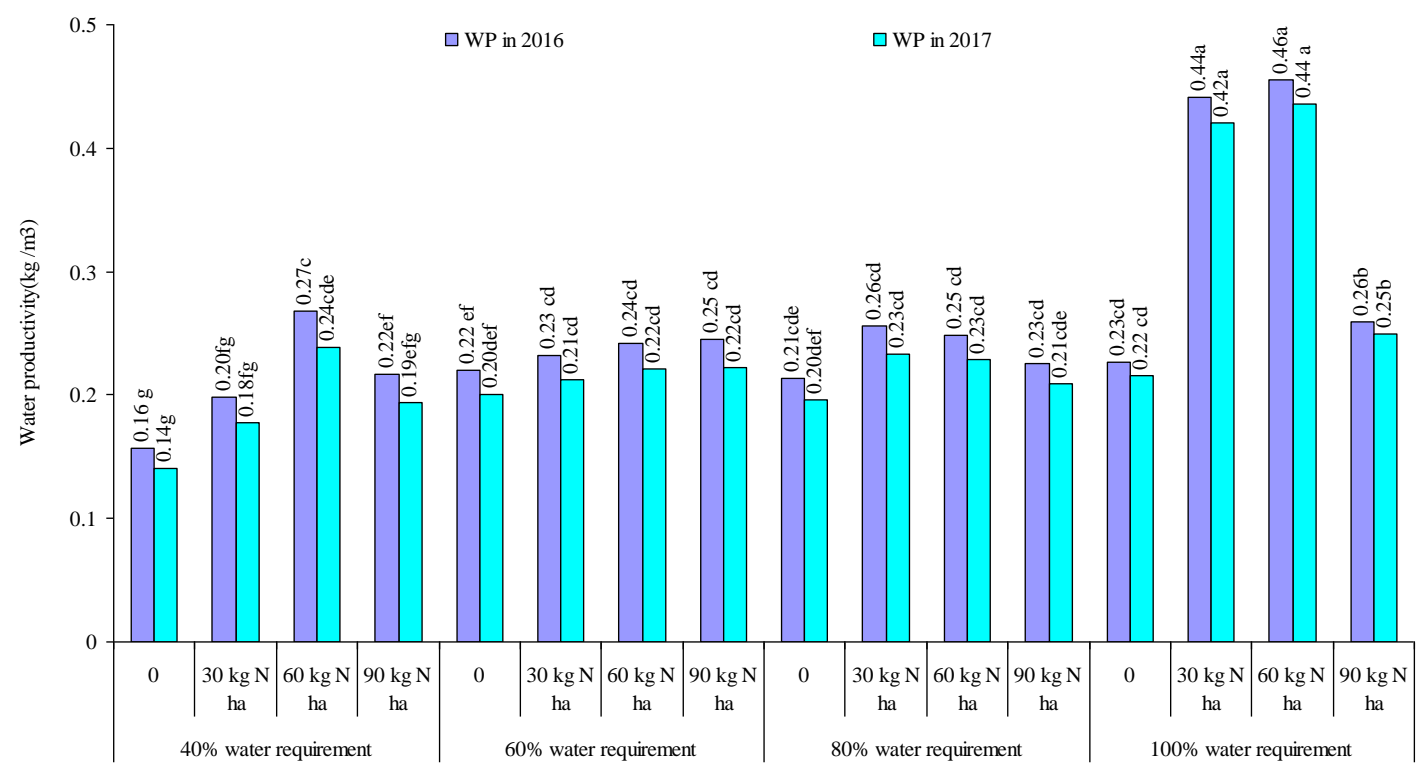

Figure 25. Interaction of irrigation, nitrogen fertilizer and cultivars on WP in 2016 and 2017

\section{Discussion}

Beans are sensitive to soil condition and drought damage and their water consumption increases with age. Irrigation is very important in water stress and showed direct effect on yield (Korir et al., 2006). Increase amount of Nitrogen to a determined level resulted in increase of yield (Singh, 2007). The results showed that moisture stress resulted in decrease of seed weight. Nitrogen influenced all elements of seeds such as number and weight. Shortage of Nitrogen in plants resulted in decrease of efficiency (Lawlor, 2001). According to Marschner (1995), high amount of Nitrogen in crops made them more sensitive to diseases.

Beans were sensitive to water shortage before and during flowering stage. In this step, shortage of water prevented the evolution of inflorescence and decreased the number of young pods and seeds (Singh, 2007; Lizana et al., 2006). High level of Nitrogen had no effect on number of pods. Authors reported the loss of legume yield in drought related to decrease of pods in crops (Singh, 2007). Long term water stress decreases the crop height. Availability of nitrogen influenced cell division and enlarged leaves (Singh, 2007). Water shortage is the most limiting factor in bean and Cowpea production, and improving agricultural Water productivity is essential for the increased leguminous demand. Conventional irrigation cannot be sustained in arid and semi-arid areas because of the rapid depletion of water resources. It is believed that conventional irrigation is a luxury use of water and can be reduced without much effect on economic yield. Methods that may cut down irrigation are of considerable interest and should be explored. Physiological water-saving irrigation strategies especially temporal and spatial deficit irrigation have great potential to practice in Leguminous production in arid and semiarid areas. It is well established that plant Seed production depends on the amount of water used for growth as well as on water productivity. The estimation of water productivity suggests that the amount of seed produced is equal to the water used during growth multiplied by Water productivity, which thus implies that the amount of Seed increases with increasing water productivity for constant water use. Therefore, 
Water productivity would be of particular interest in situations where growth is affected as a result of limiting water availability. The increased water productivity of bean and cowpea under water stress is attributed to seed production being reduced less by drought than water use.

\section{Conclusion}

The results showed that water shortage has negative influence on crop yield. The highest seed yield required $100 \%$ water and the lowest value was $40 \%$ in two varieties. The highest loss of seed yield in drought showed that supplying enough water is necessary to ensure photosynthetic elements to seeds by producing leaves and green coverage. The efficiency of water in common bean was more proper than in Cowpea. Finally based on results, it is suggested that normal beans are in priority of cultivation in studied region.

\section{REFERENCES}

[1] Anyia, A. O., Herzog, H. (2004): Water use efficiency, leaf area and leaf gas exchange of cowpeas under mid-season drought. - European Journal of Agronomy 20: 327-339.

[2] Aujla, M. S., Thind, H. S., Buttar, G. S. (2005): Cotton yield and water use efficiency at various levels of water and $\mathrm{N}$ through drip irrigation under two methods of planting. Agricultural Water Management 71: 167-179.

[3] Baker, N. R., Rosenqvist, E. (2004): Applications of chlorophyll fluorescence can improve crop production strategies: an examination of future possibilities. - Journal of Experimental Botany 55: 1607-1621.

[4] Beebe, S. E., Rao, I. M., Cajiao, C., Grajales, M. (2008): Selection for drought resistance in common bean also improves yield in phosphorus limited and favorable environments. - Crop Science 48: 582-592.

[5] Carmona-Garcia R., Osorio-Díaz, P., Agama-Acevedo, E., Tovar. J., Bello-Perez, L. A. (2007): Composition and effect of soaking on starch digestibility of Phaseolus vulgaris (L.). - International Journal of Food Science and Technology 42: 296-302.

[6] Clavel, D., Drame, N. K., Roy-Macauley, H., Braconnier, S., Laffray, D. (2005): Analysis of early responses to drought associated with field drought adaptation in four Sahelian groundnut (Arachis hypogaea L.) cultivars. - Environmental and Experimental Botany 54: 219-230.

[7] Fageria, N. K., Santos, A. B. (2008): Yield physiology of dry bean. - Journal of Plant Nutrition 31: 983-1004.

[8] Hall, A. E., Cisse, N., Thiaw, S., Elawad, H. O. A., Ehlers, J. D., Ismail, A. M., Fery, R. L., Roberts, P. A., Kitch, L., WMurdock, L. L., Boukar, O., Phillips, R. D., McWatters, K. H. (2003): Development of cowpea cultivars and germplasm by the Bean/Cowpea CRSP. - Field Crops Research 82: 103-134.

[9] Jean-Martial, J., Houngnandana, P., Kaneb, A., Sanonc, K. B., Neyrad, M. (2013): Diversity patterns of indigenous arbuscular mycorrhizal fungi associated with rhizosphere of cowpea (Vigna unguiculata (L.) Walp.) in Benin, West Africa. - International Journal of Soil Biology 56(3): 121-128.

[10] Korir, P. C., Nyabundi, J. O., Kimurto, P. K. (2006): Genotypic responses of common bean (Phaseolus vulgaris L.) to moisture stress conditions in Kenya. - Asian Journal of Plant Sciences 5: 24-32. 
[11] Kotchoni, S. O., Bartels, D. (2003): Water stress induces the up-regulation of a specific set of genes in plants: Aldehyde dehydrogenases as an example. - Bulgarian Journal of Plant Physiology 2003(Special Issue): 37-51.

[12] Lawlor, D. W., Lemaire, G., Gastal, F. (2001): Nitrogen, plant growth and crop yield. In: Lea, P. J., Morot-Gaudry, J. F. (eds) Plant Nitrogen, pp. 343-367. Springer, Berlin.

[13] Lizana, C., Wentworth, M., Martinez, J. P., Villegas, D., Meneses, R., Murchie, E. H. (2006): Differential adaptation of two varieties of common bean to abiotic stress. I. Effect of drought on yield and photosynthesis. - Journal of Experimental Botany 57: 685-697.

[14] Marschner, H. (1995): Mineral Nutrition of Higher Plants, $2^{\text {nd }}$ ed. - Academic Press, San Diego.

[15] Passioura, J. B. (2006): Increasing crop productivity when water is scarce from breeding to field management. - Agricultural Water Management 80: 176-196.

[16] Shardendu, K., Singh, K., Reddy, R. (2011): Regulation of photosynthesis, fluorescence, stomatal conductance and water-use efficiency of cowpea (Vigna unguiculata [L.] Walp.) under drought. - Journal of Photochemistry and Photobiology 105: 40-50.

[17] Singh, B. B. (2004): Cowpea (Vigna unguiculata (L.) Walp.). - In: Singh, R. J., Jauhar, P. P. (eds.) Genetic Resources, Chromosome Engineering, and Crop Improvement, pp. 117161. CRC Press, Boca Raton, FL, USA.

[18] Singh, S. P. (2007): Drought resistance in the race Durango dry bean landraces and cultivars. - Agronomy Journal 99: 1219-1225. 